I Made Sudarma, dkk. : Persepsi Masyarakat terhadap Ekosistem Daerah Aliran Sungai Ayung .....

\title{
PERSEPSI MASYARAKAT TERHADAP EKOSISTEM DAERAH ALIRAN SUNGAI AYUNG MENUJU SUMBERDAYA AIR BERKELANJUTAN
}

\author{
I Made Sudarma*, Wayan Widyantara \\ Program Studi Agribisnis, Fakultas Pertanian, Universitas Udayana \\ *Email : sudarmaimade@yahoo.com
}

\begin{abstract}
The sustainability of watershed ecosystem functions in managing the water system can be achieved if the utilization pattern of their territories in accordance with the rules of conservation. A decrease in quantity and quality of the river water can be an indicator that condition of the watershed have been damaged. The destruction of the watershed ecosystem as a result of various causes will be able to threaten supply of sustainable water resources. The aim of this research is to determine and analyze the perceptions and behavior of upstream communities and governments about the function and role of water conservation and watershed in their behavior in the preservation of the watershed and its relationship with the current condition of the Ayung river. The study was conducted in the area upstream of Ayung river, which is in the Belok Sidan and Plaga Village, Petang, Badung, stake holder water users Ayung River such as PDAM, AMDK, rafting and farmers, as well as the government of Badung Regency that responsible for the management and conservation of Ayung River. Results of the study found that the public perception of the functions and benefits of watershed in the conservation of water resources classified in the category of high, but was followed by actions or attitudes in the medium category. There was no real relationship between perception and action, but the action affect current watershed conditions. The role and participation of stakeholders Ayung River water users were still relatively low in the preservation of the watershed, while the government's role classified as medium has not been done in an integrated among sectors and regions. From the results of this study it is recommended that the preservation of the Ayung river through various conservation action were integrated by involving communities upstream more active through the empowerment of local knowledge and improve their welfare. Government plays an important role in moving towards unity of this act.
\end{abstract}

Keywords: watershed; water; conservation; sustainable

\begin{abstract}
Abstrak
Keberlanjutan fungsi ekosistem DAS dalam mengatur tata air dapat tercapai apabila pola pemanfaatan kawasannya sesuai dengan kaidah-kaidah konservasi. Penurunan kuantitas dan kualitas air sungai dapat menjadi indikator bahwa kondisi DAS telah mengalami kerusakan. Rusaknya ekosistem DAS akibat dari berbagai sebab akan dapat mengancam penyediaan sumberdaya air berkelanjutan. Tujuan penelitian adalah untuk mengetahui dan menganalisis persepsi dan perilaku masyarakat hulu serta pemerintah tentang fungsidan peranan DAS dalam konservasi air serta perilaku mereka dalam upaya pelestarian DAS serta hubungannya dengan kondisi DAS Ayung saat ini.Penelitian dilakukan di wilayah hulu DAS Ayung, yaitu di Desa Belok Sidan dan Desa Plaga, Kecamatan Petang, Kabupaten Badung, stake holder pengguna air sungai ayung seperti PDAM, AMDK, rafting dan petan, serta pihak pemerintah Kabupaten Badung selaku pihak yang bertanggung jawab dalam pengelolaan dan pelestarian DAS Ayung. Hasil penelitian
\end{abstract}


mendapatkan bahwapersepsi masyarakat hulu terhadap fungsi dan manfaat DAS dalam pelestarian sumberdaya air tergolong dalam katagori tinggi,namundiikuti oleh tindakan atau sikap dalam katagori sedang. Tidak ada hubungan yang nyata antara persepsi dengan tindakan, namun tindakan berpengaruh terhadap kondisi DAS saat ini. Peranan dan partisipasi stake holder pengguna air Sungai Ayung masih tergolong rendah dalam pelestarian DAS sedangkan peranan pemerintah tergolong sedang dan belum dilakukan secara terpadu dan terintegrasi antar sektor dan antar wilayah. Dari hasil penelitian ini disarankan agar pelestarian DAS Ayung dilakukan melalui berbagai tindakan konservasi yang terpadu dan terintegrasi dengan melibatkan peran serta masyarakat hulu lebih aktif melalui pemberdayaan kearifan lokal dan peningkatan kesejahteraan mereka. Pemerintah memegang peranan penting dalam menuju kesatuan tindak ini.

Kata kunci: DAS; air; pelestarian; berkelanjutan

\section{Pendahuluan}

\subsection{Latar Belakang}

Ekosistem daerah aliran sungai (DAS) di daerah hulu yang berupa kawasan hutan memegang peranan penting dalam menjaga kelangsungan proses hidrologi, mencegah terjadinya erosi dan sedimentasi. Eksploitasi sumberdaya hutan dan perubahan tata guna lahan di kawasan hulu yang tidak mempertimbangkan aspek lingkungan akan merusak ekosistem DAS. Kerusakan hutan dan lahan dalam satuan wilayah DAS di berbagai daerah terus terjadi bahkan ada kecenderungannya terus meningkat. Tingginya laju kerusakan hutan yang mencapai 1,6 juta ha/tahun jauh melebihi dari kemampuan untuk merehabilitasinya yang hanya sekitar 900.000 - 1,2 juta ha/tahun (Menhut, 2009 ).Keadaan ini bisa terjadi akibat dari tingkat partisipasi masyarakat dalam pengelolan DAS masih rendah, banyak proyek-proyek yang keberhasilannya sulit dipertahankan,kebijakan antar pemerintah dan pemangku kepentingan (stake holder) lain sering tidak sejalan (conflict of interest), dan intervensi masyarakat dalam pemanfaatan lahan hutan dan DAS semakin intensif.

Penerapan nilai-nilai pengelolan hutan dan DAS lestari masih rendah dan belum sepenuhnya diikuti oleh partisipasi masyarakat. Salah satu penyebabnya adalah strategi yang dilaksanakan pemerintah selama ini kurang melibatkan masyarakat. Keterlibatan mereka dalam pengelolaan hutan dan DAS sangat terbatas bahkan di beberapa daerah menjadi hilang. Hal ini membuat masyarakat merasa asing terhadap lingkungannya sendiri bahkan lebih jauh lagi adalah tidak adanya rasa memiliki atas hutan yang ada di sekelilingnya. Paradigma yang berkembang adalah bahwa problema pengelolaan hutan dan lahan bukanlah problema masyarakat akan tetapi merupakan masalah pemerintah.Paradigma ini terjadi karena kegiatan yang dilakukan oleh pemerintah bersifat top down dan instruksional serta kurang memperhatikan pelibatan masyarakat dan pemangku kepentingan lainnya.

Kemampuan DAS untuk menahan dan menyimpan air sangat bergantung pada jenis dan kondisi vegetasi yang tumbuh di atasnya serta kondisi tanah. Oleh sebab itu, hilangnya tutupan vegetasi di daerah resapan air maupun kawasan lindung di willayah hulu DAS akan mengganggu pasokan dan kualitas air ke daerah tengah dan hilir karena terganggunya fungsi hidrologis. Manfaat konservasi tanah dan air pada ekosistem DAS tidak hanya dirasakan oleh masyarakat hulu semata, tetapi keberadaan ekosistem ini sangat menentukan keberlanjutan ketersediaan sumberdaya air di masa depan.

Bahayaekologis,sepertibanjirdi kawasan hilirakan sangat berpeluang muncul manakala sistem ekologis di kawasan hulu tidak berfungsi dengan baik dalam menahan laju air yang datang akibat hujan (Dharmawan, 2005). Banjir dan sedimentasi di kawasan hilir akan sangat 
berpeluang muncul manakala sistem ekologis di kawasan hulu tidak berfungsi dengan baik. Fakta ini juga menunjukkan betapa pentingnya suatu kesatuan sistem kebijakan sumber daya alam dan lingkungan pada sekatan-sekatan kawasan DAS. Ketidakselarasan sistem pengelolaan dan kebijakan sumber daya alam dan lingkungan yang berlaku di kawasan hulu-tengah-hilir pada sebuah DAS, akan menghasilkan kekacauan sistem tata air secara keseluruhan di DAS yang bersangkutan.

Rumusan hasil Lokakarya berterna "Membangun Kapasitas Para Pihak Untuk Penyelarnatan DAS yang diselenggarakan oleh Menteri Kehutanan ( 2009) menyimpulkan bahwa kondisi DAS di Indonesia semakin memprihatinkan. Banyak DAS yang mengalami penurunan kualitas dengan indikasi meningkatnya luaslahan kritis, semakin seringnya banjir, kekeringan, tanah longsor dan pencemaran air yang merugikan kehidupan masyarakat dan lingkungan. Penurunan kualitas DAS ini disebabkan antara lain oleh beberapa hal seperti tekanan penduduk yang meningkat akibat dari pembangunan industri, pembangunan infrastruktur, dan berkembangnya pemukiman, dijadikannya sebagai tempat pembuangan limbah padat (sampah) dan limbah cair, rendahnya kapasitas institusi yang bertugas mencegah dan merehabilitasi kerusakan sumberdaya, kebijakan yang belum berpihak kepada pelestarian sumberdaya alarn (SDA), koordinasi yang belum optimal antar stakeholder terkait, dan kesadaran serta partisipasi berbagai pihak termasuk sebagian masyarakat yang masih kurang dalam konteks pemanfaatan dan pelestarian SDA.

Provinsi Bali memiliki 401 sungai yang 162 sungai diantaranya bermuara di laut. Dari 162 sungai tersebut hanya 11 sungai yang memiliki DAS dengan luasan lebih dari $100 \mathrm{Km}^{2}$. Seluruh DAS di Provinsi Bali terbagi ke dalam 12 satuan wilayah pengelolaan (SWP) berada dalam wilayah pengelolaan BP DAS Unda Anyar. DAS Ayung merupakan salah satu DAS dari SWP Pangi Ayung yang terdiri dari tujuh DAS, yaitu DAS Ayung, DAS Badung, DAS Nyali, DAS Mati, DAS Yeh
Poh, DAS Canggah, dan DAS Pangi. DAS Ayung merupakan DAS terpanjang di antara ketujuh DAS tersebut dengan panjang sekitar $68,5 \mathrm{~km}$ dan lebar 4,39 Km.

Sungai Ayung adalah sungai utama yang mengalir di wilayah DAS Ayung. DAS Ayung mempunyai luas 30.981 ha dengan wilayah terluas berada di Kabupaten Badung, yaitu mencapai 14.358 ha $(46,34 \%)$. Kabupaten Badung juga merupakan kabupaten pemanfaat air terbesar dari Sungai Ayung mulai dari untuk kebutuhan masyarakat seperti mandi, cuci dan kakus, tempat kegiatan sosial dan budaya (melasti, nganyut, melukat) dan juga dimanfaatkan untuk pertanian, bahan baku air PDAM, rafting dan juga untuk memproduksi air mineral dalam kemasan (AMDK).

Kegiatan pelestarian ekosistem hutan dan DAS memerlukan pelibatan banyak pihak, meliputi masyarakat hulu (pihak penyedia air), masyarakat hilir (pihak pengguna air) dan pemerintah sebagai operator dan regulator sumberdaya air. Memberikan tanggung jawab sepenuhnya hanya kepada masyarakat hulu dalam kegiatan konservasi ekosistem DAS merupakan bentuk ketidakadilan karena konservasi DAS juga memberi manfaat keberlanjutan ketersediaan air bagi masyarakat hilir. Pihak pengguna air di daerah hilir perlu berkontribusi terhadap masyarakat hulu yang telah berjasa dalam menjaga ekosistem DAS dari ancaman degradasi. Terciptanya mekanisme kontribusi ini diharapkan menjadi instrumen kebijakan pemerintah dalam upaya konservasi DAS di daerah hulu. Sebelum instrumen kebijakan tersusun maka penting untuk diketahui bagaimanakah persepsi dan perilaku masyarakat hulu, hilir dan pemerintah dalam memahami fungsi ekosistem DAS dan pengelolaannya.

\subsection{Tujuan Penelitian}

Air adalah komoditi yang tidak memiliki substitusi sehingga pelestariannya mutlak perlu dilakukan untuk terjadinya kehidupan berkelanjutan. Daerah hulu dengan ekosistem 
hutan dan DAS nya adalah merupakan catchment area yang memegang peranan penting dalam menjaga siklus hidrologi (tata air) untuk keberlanjutan pasokan air baku. Memberikan tanggung jawab sepenuhnya hanya pada masyarakat hulu semata untuk menjaga ekosistem DAS di hulu adalah bentuk ketidakadilan karena manfaat atas berfungsinya ekosistem tersebut tidak hanya diterima oleh masyarakat hulu, tetapi juga masyarakat hilir dan pemerintah. Adanya manfaat ekonomi dan non ekonomi yang diterima para pihak seharusnya menjadikan tanggung jawab pelestarian ekosistem DAS di hulu menjadi tanggung jawab bersama.

Berangkat dari latar belakang tersebut di atas maka tujuan utama penelitian ini adalah mengetahui persepsi para pihak (masyarakat hulu, masyarakat hilir dan pemerintah) dalam memahami fungsi DAS dan sikap serta perilaku yang ditunjukkan atas pemahaman tersebut. Secara lebih spesifik, tujuan penelitian ini adalah untuk :

1. Mengetahui kondisi ekosistem DAS Ayung di daerah hulu.

2. Menganalisis persepsi dan perilaku masyarakat hulu dan hilir dalam pelestarian ekosistem DAS Ayung.

3. Menganalisis hubungan antara persepsi dengan perilaku masyarakat dalam pelestarian ekosistem DAS Ayung

\section{Metode Penelitian}

\subsection{Lokasi Penelitian}

Penelitian ini dilakukan di wilayah DAS Ayung yang secara administratif berada di wilayah Kabupaten Badung. Pemilihan Kabupaten Badung sebagai lokasi penelitian karena wilayah DAS Ayung terluas berada di Kabupaten Badung dan pihak pemanfaatan air Sungai Ayung terbesar juga berada di wilayah Kabupaten Badung.

\subsection{Sumber Data}

Data yang dikumpulkan dalam penelitian ini adalah kuantitatif (numerikal) dan kualitatif (katagorikal). Data kuantitatif menyangkut kondisi umum geografis wilayah DAS dan tingkat pendapatan masyarakat sekitar DAS, sedangkan data kualitatif adalah data katagorikal yang menyangkut persepsi masyarakat terhadap fungsi DAS sebagai tata air dan dan perilaku masyarakat dalam pelestarian DAS menuju keberlanjutan aliran air di Sungai Ayung.

Data berdasarkan sumbernya dibedakan menjadi dua, yaitu data primer dan data sekunder. Data primer adalah data yang diperoleh secara langsung dari responden terpilih melalui wawancara dengan menggunakan kuesioner (daftar pertanyaan). Responden dalam penelitian ini dibedakan menjadi tiga kelompok, yaitu responden dari kelompok masyarakat di wilayah hulu DAS sebagai representasi masyarakat penyedia air, responden dari masyarakat yang berada di wilayah tengah dan hilir DAS sebagai representasi kelompok masyarakat pemakai air.

Data sekunder adalah data yang diperoleh dari berbagai sumber informasi kedua, khususnya dari berbagai instansi terkait yang ada di tingkat provinsi dan kabupaten/kota di Bali seperti Biro/Kantor Pusat Statistik, Dinas Kehutanan, Dinas Pekerjaan Umum, Bappeda, Badan Lingkungan Hidup, serta berbagai publikasi hasil studi yang relevan dengan penelitian ini baik di tingkat regional, nasional maupun internasional.

Dalam pengumpulan data metode yang dipergunakan dalam penelitian ini adalah metode survei, yaitu metode yang mengambil sampel dari suatu populasi dengan menggunakan kuesioner sebagai alat pengumpulan data yang pokok (Singarimbun, dkk., 1989). Dilihat dari teknik yang dipergunakan dalam metode survei ini akan dipergunakan metode triangulasi yang meliputi kegiatan observasi, wawancara, dan daftar pertanyaan (Sugiyono, 2010).

\subsection{Populasi dan Responden Penelitian}

Penelitian dilakukan pada daerah hulu DAS Ayung. Diasumsikan bahwa masyarakat hulu adalah masyarakat penyedia air oleh karena keberadaan ekosistem hutan dan DAS di daerah hulu sangat menentukan fungsi hidrologis 
ekosistem tersebut dalam menjaga tanah dan taat air. Perilaku masyarakat hulu melalui tindakan pelestarian, konservasi dan rehabilitasi sangat berperan dalam menjaga kelestarian ekosistem DAS di bagian hulu. Populasimasyarakat hulu dalam penelitian ini diwakili secara purposive oleh masyarakat Desa Belok Sidan dan Desa Plaga, Kecamatan Petang, Kabupaten Badung.

Jumlah responden untuk tujuan penelitianini ditetapkan secara purposive di masing-masing desa, masing-masing sebanyak 25 orang yang dipilih melalui simple random sampling. Dengan demikian jumlah responden untuk penelitian ini seluruhnya berjumlah 50 orang.

\subsection{Analisis Data}

Metode analisis data yang digunakan untuk mengetahui persepsi dan perilaku masyarakat akan pentingnya peranan DAS Ayung di hulu adalah deskriptif kualitatif dengan menggunakan teknik skor pada tiap komponen. Salah satu cara yang digunakan dalam menentukan skor adalah dengan menggunakan skala likert. Dengan menggunakan skala likert, nilai peringkat setiap jawaban atau tanggapan dijumlahkan sehingga mendapatkan nilai total. Analisis dengan skala likert disesuaikan dengan tujuan penelitian dan memberikan gambaran sesuai dengan jumlah dan persen untuk setiap kategori. Pemberian skor dilakukan secara konsisten dengan memberikan bilangan bulat 1, 2, 3, 4 dan 5 pada setiap kemungkinan jawaban yang diberikan. Skor tertinggi diberikan untuk jawaban yang paling diharapkan, sedangkan skor terendah diberikan untuk jawaban yang paling tidak diharapkan. Untuk setiap pernyataan disediakan sejumlah alternatif tanggapan yang berjenjang atau bertingkat. Dalam penelitian ini jumlah alternatif yang digunakan adalah 5 (sangat baik, baik, cukup baik, kurang baik dan sangat tidak baik). Adapun cara pemberian skor terhadap setiap pertanyaan yang diajukan kepada responden sebagai berikut.

a. Skor 1 diberikan apabila responden memberikan pendapat atau tanggapan yang paling tidak diharapkan (sangat tidak baik) b. Skor 2 diberikan apabila responden memberikan pendapat atau tanggapan yang tidak diharapkan (kurang baik)

c. Skor 3 diberikan apabila responden memberikan pendapat atau tanggapan yang meragukan (cukup baik)

d. Skor 4 diberikan apabila responden memberikan pendapat atau tanggapan yang paling yang diharapkan ( baik)

e. Skor 5 diberikan apabila responden memberikan pendapat atau tanggapan yang paling diharapkan (sangat baik)

Analisis data yang digunakan disesuaikan dengan tujuan dari masing-masing penelitian sebagai berikut.

1. Tujuan penelitian yang pertama yakni mengetahui kondisis ekosistem DAS di daerah hulu dideskripsikan menggunakan pendekatan lingkungan, kemudian dianalisis menggunakan metode deskriptif kualitatif yaitu mendeskripsikan kondisis geofisik dan biofisik DAS serta pemanfaat Sungai Ayung,

2. Tujuan penelitian yang kedua yaitu persepsi dan perilaku masyarakat hulu dan hilir dalam pelestarian ekosistem DAS Ayung dianalisis dengan menggunakan metode deskriptif kualitatif yaitu mendeskripsikan kesesuaian data tentang persepsi dan perilaku masyarakat terhadap ekosistem DAS yang diperoleh di lapangan dengan teori yang dibangun dalam kajian pustaka. Komponen dari persepsi dan perilaku hasil jawaban responden selanjutnya dibuatkan skor. Penentuan skor diawali dengan menjumlahkan skor masing-masing komponen dengan nilai skor maksimal 5,0 dan skor minimal 1,0. Tahap selanjutnya yaitu menghitung kelas interval dengan cara selisih skor maksimum dan skor minimum dibagi kelas interval. Konklusinya adalah sebagai berikut.
$1,0-2,2=$ tingkat persepsi rendah
$2,3-3,6=$ tingkat persepsi sedang
$3,7-5,0=$ tingkat persepsi tinggi 
3. Tujuan penelitian yang ketiga yakni mengenai hubungan antara persepsi dengan perilaku masyarakat petani terhadap pelestarian ekosistem DAS Ayung dianalisis dengan analisis bivariat. Analisis bivariat digunakan untuk mengetahui hubungan antara variabel bebas dengan variabel terikat. Analisis bivariat dalam penelitian ini menggunakan analisis korelasi Spearman Rank. Astawa (2011) mengungkapkan koefisien dari Spearman Rank juga dikenal dengan koefisien Tata Jenjang. Korelasi Tata Jenjang dapat digunakan jika kedua gejala yang dikorelasikan berbentuk gejala ordinal. Penggunaan Korelasi Spearman Rank tidak memprasyaratkan bahwa sumber data untuk kedua variabel yang akan dikorelasikan berasal dari sumber yang sama, dan juga tidak memprasyaratkan bahwa data harus berdistribusi normal. Rumus yang digunakan adalah sebagai berikut.

$\mathrm{rho}_{\mathrm{xy}}=1-\frac{6 \sum \mathrm{D}^{2}}{\mathrm{n}\left(\mathrm{n}^{2}-1\right)}$

Keterangan:

rho $_{x y} \quad$ : Koefisien korelasi tata jenjang

$\sum \mathrm{D}^{2}$ : Kwadrat selisih antara rangking $\mathrm{x}$ dan y

n : Jumlah sampel

Uji signifikan Korelasi Tata Jenjang (rho) dari Spearman adalah dengan membandingkannya terhadap harga kritik rho yang terdapat dalam tabel statistik rho jika jumlah sampel maksimal 30. Tetapi karena sampel yang digunakan dalam penelitian ini jumlahnya lebih dari 30 orang, maka pengujian signifikasinya menggunakan uji $\mathrm{t}$ dengan rumus sebagai berikut.

$t=\operatorname{rho} \sqrt{\frac{n-2}{1-\text { rho }^{2}}}$

Jika sudah diketahui $t_{\text {hitung }}$ maka dapat ditarik simpulan bahwa apabila $t_{\text {hitung lebih besar }}$ dari $t_{\text {tabel }}$ maka hipotesis Ha diterima dan apabila $t_{\text {hitung }}$ lebih kecil dari $t_{\text {tabel }}$ maka Ha ditolak.

\section{Hasil dan Pembahasan}

\subsection{Kondisi Umum DAS Ayung}

a. Letak dan luas wilayah DAS

Provinsi Bali memiliki 401 sungai yang 162 sungai diantaranya bermuara di laut. Dari 162 sungai tersebut hanya 11 sungai yang memiliki DAS dengan luasan lebih dari $100 \mathrm{Km}^{2}$. DAS Ayung merupakan bagian dari Satuan Wilayah Pengelolaan (SWP) Pangi Ayung, yang terdiri dari tujuh DAS, yaitu DAS Ayung, DAS Badung, DAS Nyali, DAS Mati, DAS Yeh Poh, DAS Canggah, dan DAS Pangi. DAS Ayung merupakan DAS terpanjang di antara ketujuh DAS tersebut dengan panjang sekitar 68,5 km dan lebar 4,39 Km. Letak atau posisi DAS Ayung sebagai salah satu DAS di Provinsi Bali dapat dilihat pada Gambar 1. 


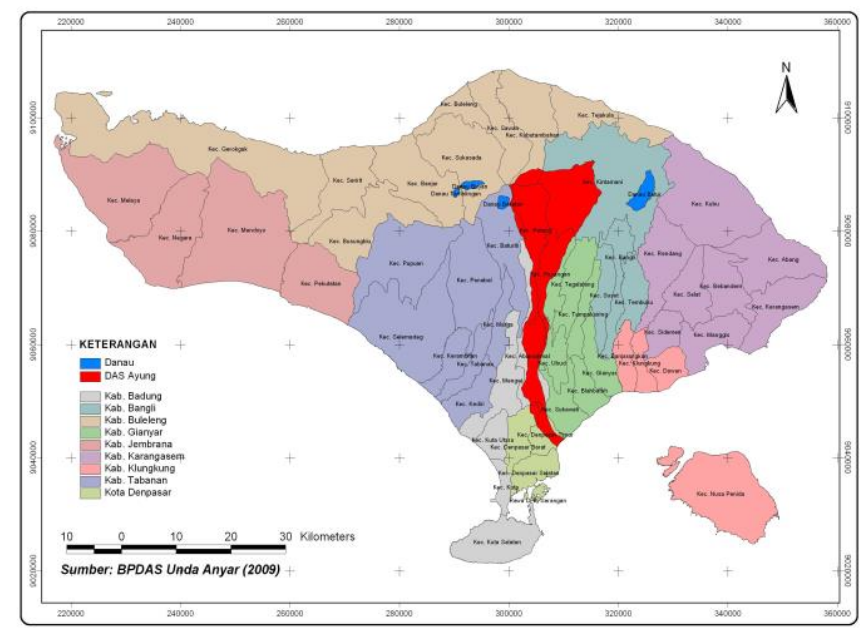

Gambar 1. Peta DAS Ayung

DAS Ayung mempunyai luas wilayah 30.981 Ha berhulu di Kabupaten Buleleng, Bangli dan Badung serta berhilir di Kota Denpasar. Wilayah DAS ini berada di sembilan wilayah kecamatan dengan 59 desa administratif seperti terlihat pada Tabel 1. Sebagian besar wilayah DAS Ayung berada di wilayah Kabupaten Badung yang luasannya mencapai $14.358 \mathrm{Ha}(46,34 \%)$ atau hampir mendekati setengahnya dari luasan wilayah DAS keseluruhan. Sebaliknya luasan tersempit berada di Kabupaten Buleleng, tepatnya berada di Desa Belok Sidan, Kecamatan Kubutambahan yang merupakan salah satu hulu DAS Ayung dengan luas wilayah $458 \mathrm{Ha}$ atau hanya sekitar 1,48 \% dari total luasan DAS Ayung (BPDAS Unda Anyar, 2009).

Tabel 1. Persebaran Luas Wilayah DAS Ayung Berdasar Daerah Adminitratif, Tahun 2011

\begin{tabular}{cllrrr}
\hline No. & \multirow{2}{*}{ Kabupaten/ Kota } & Kecamatan & $\begin{array}{c}\text { Jumlah } \\
\text { Desa }\end{array}$ & $\begin{array}{r}\text { Luas Wilayah } \\
(\text { Ha) }\end{array}$ & $\begin{array}{c}\text { Persentase } \\
(\%)\end{array}$ \\
\hline 1. & Buleleng & Kubutambahan & 1 & 458,00 & 1,48 \\
2. & Bangli & Kintamani & 24 & $8.872,00$ & 28,63 \\
3. & Badung & Petang & 7 & $9.439,00$ & 30,47 \\
& & Abiansemal & 14 & $4.919,00$ & 15,88 \\
4. & Tabanan & Baturiti & 1 & 483,00 & 1,56 \\
5. & Gianyar & Payangan & 6 & $4.453,00$ & 14,37 \\
& & Ubud & 2 & 402,00 & 1,30 \\
6. & Denpasar & Denpasar Utara & 2 & 983,00 & 3,17 \\
& & Denpasar Timur & 4 & 972,00 & 3,14 \\
Jumlah & & & 59 & $30.981,00$ & 100,00 \\
\hline
\end{tabular}

Sumber : BPDAS Unda Anyar, 2009

Rata-rata curah hujan tahunan di wilayah DAS Ayung adalah $1558 \mathrm{~mm}$ dengan curah hujan rata-rata bulanan tertinggi terjadi pada bulan Januari $(487 \mathrm{~mm})$ dan terendah terjadi pada bulan September $(15 \mathrm{~mm})$. Jumlah hari hujan rata-rata dalam setahun adalah 145 hari, dengan hari hujan rata-rata per bulan tertinggi terjadi pada bulan Januari (27 hari) dan terendah pada bulan September (4 hari). Dengan demikian dapat dikatakan bahwa di lokasi penelitian terdapat 2 
pola musim dalam satu tahun yaitu musim penghujan (bulan Nopember sampai dengan April) dan musim kemarau (Juni sampai Oktober), sedangkan bulan Mei merupakan peralihan dari musim hujan ke musim.

\section{b. Tata guna lahan}

Berdasarkan data dari BPDAS Unda Anyar (2009), DAS Ayung dengan luas mencapai 30.981 Ha pemanfaatan lahannya didominasi untuk penggunaan kebun/perkebunan, yaitu seluas
14.593Ha atau sekitar 47,10\%, kemudian diikuti oleh penggunan lahan untuk tegalan/ladang seluas $4.485 \mathrm{Ha}(14,47 \%)$, penggunaan untuk lahan sawah irigasi seluas $3.723 \mathrm{Ha}(12,07 \%)$, dan untuk pemukiman seluas $1.542 \mathrm{Ha}(4,97 \%)$. Luasan untuk semak, sawah tadah hujan, dan hutan masing-masing adalah seluas3.457Ha, $1.572 \mathrm{Ha}$, dan 1.609 Ha. Untuk jelasnya tipe dan luasan penggunaan lahan di DAS Ayung untuk berbagai peruntukan dapat dilihat pada Tabel 2 .

Tabel 2. Tipe dan Luas Penggunaan Lahan di DAS Ayung, Tahun 2009

\begin{tabular}{clcc}
\hline No. & \multicolumn{1}{c}{ Tipe Penggunaan Lahan } & Luas (ha) & Persentase $(\%)$ \\
\hline 1. & Semak /belukar & 3.457 & 11,15 \\
2. & Sawah tadah hujan & 1.572 & 5,06 \\
3. & Hutan & 1.609 & 5,18 \\
4. & Kebun/Perkebunan & 14.593 & 47,10 \\
5. & Pemukiman & 1.542 & 4,97 \\
6. & Tegalan/ladang & 4.485 & 14,47 \\
7. & Sawah irigasi & 3.723 & 12,07 \\
& TOTAL & 30.981 & 100,00 \\
\hline
\end{tabular}

Sumber : BPDAS Unda Anyar, 2009

\section{c. Pemanfaat air Sungai Ayung}

Pada awalnya pola pemanfaatan DAS Ayung di bagian hulu adalah merupakan kawasan hutan dan lahan pertanian semusim, sedangkan di bagian tengah hinga hilir di dominasi oleh lahan persawahan. Disamping untuk pertanian, penduduk yang bermukim di dekat dengan aliran Sungai Ayung memanfaatkan air sungai sebagai tempat mandi, mencuci dan kakus (MCK). Bali dengan penduduknya yang mayoritas beragama Hindu, juga memanfaatkan sungai sebagai tempat untuk melangsungkan kegiatan ritual keagamaan, seperti untuk upacara melasti, nganyut, melukat, dan upacara lainnya yang bermakna "membersihkan" atau "menyucikan" dari segala kekotoran. Bahkan sungai juga dipergunakan sebagai tempat mencari nafkah hidup bagi sebagian masyarakat, seperti tempat untuk menangkap ikan dan tempat untuk mencari atau menambang pasir di era tahun 1970-an.
Namun demikian, sejalan dengan perkembangan pembangunan di Bali dimana pembangunan sektor pariwisata lebih dominan dibandingkan dengan pembangunan sektor-sektor lainnya, maka pemanfaatan air Sungai Ayung juga berkembang sesuai dengan dengan kebutuhan masing-masing sektor. Atas dasar potensi yang dimiliki DAS Ayung, baik dilihat dari potensi aliran airnya (debit) maupun potensi pemandangan (lenskap) pada aliran Sungai Ayung dan DAS Ayung dijumpai usaha wisata arung jerang (rafting) dan sarana akomodasi berupa hotel, villa, dan sejenisnya termasuk restoran, rumah makan dan bar. Kegiatan rafting di Sungai Ayung banyak menyediakan pemandangan yang indah seperti air terjun, pahatan relief di tebing sungai serta suasana dan suara alam yang relatif masih alami. Di tepi sebelah timur sungai terdapat hotel berbintang serta villa dan di tepi sebelah barat merupakan areal persawahan dan tegalan. Karena karakteristik 
Sungai Ayung yang bertebing ini menjadikan jalan turun menuju air sungai dipenuhi dengan undakan yang cukup terjal.

Pengelolaan DAS Ayung sebagai bagian dari pembangunan wilayah Bali sampai saat ini menghadapi berbagai masalah yang kompleks dan saling terkait. Permasalahan tersebut antara lain terjadinya erosi, pencemaran air sungai, banjir, kekeringan, dan belum adanya keterpaduan antar sektor atau antar instansi dalam pengelolaannya dan kesadaran masyarakat yang rendah tentang pelestarian manfaat sumber daya alam. Merosotnya kondisi DAS itu umumnya disebabkan oleh berbagai faktor, antara lain adalah karena adanya tekanan penduduk, tekanan pembangunan, dan tekanan sosial ekonomi masyarakat di kawasan DAS. Hasil penelitian PPLH (Pusat Penelitian Lingkungan Hidup) Universitas Udayana (2004), Adnyana (2007), BPDAS Unda Anyar (2009), mengungkapkan bahwa permasalahan yang telah terjadi di DAS Ayung diantaranya adalah: (a) berkurangnya penutupan vegetasi permanen terutama di bagian tengah dan hulu DAS; (b) dilakukannya budidaya tanaman semusim pada lahan yang kelas kemampuan dan kesesuaiannya tergolong tidak sesuai; (c) tingkat erosi yang tinggi di bagian tengah dan hulu DAS ; (d) semakin menurunnya kualitas air Sungai Ayung ; (e) kurangnya kesadaran dan partisipasi masyarakat terhadap kelestarian DAS; (f) rendahnya kemampuan masyarakat untuk melakukan usaha konservasi di hulu DAS; dan (g) terjadinya konflik kepentingan dalam pemanfaatan Sungai Ayung.

\subsection{Persepsi Masyarakat Hulu Terhadap DAS}

Persepsi merupakan suatu proses yang didahului oleh suatu penginderaan yaitu proses yang berwujud diterimanya stimulus oleh individu melalui alat reseptornya. Menurut Basyuni dalam Sandi (2006), faktor-faktor dalam individu yang menentukan persepsi adalah kecerdasan, emosi, minat, pendidikan, pandapatan dan kapasitas indera. Faktor luar diri individu yang mempengaruhi persepsi adalah pengaruh kelompok, pengalaman masalalu dan latar belakang sosial budaya.

Persepsi bisa menjadi hal yang vital dalam mempengaruhi perilaku seseorang dalam menjaga kualitas lingkungannya, termasuk masyarakat hulu dalam menjaga kelestarian ekosistem DAS dalam keberlanjutan ketersediaan air. Manusia akan menjadi semakin tahu dan sadar akan dampak yang dihasilkan dari adanya perubahan ekosistem. Keberadaan ekosistem DAS sangat mempengaruhi keberlanjutan pasokan air pada badan sungai. Masyarakat yang memilikipengetahuan mengenaiperanan ekosistem DAS umumnya akan bertindakreaktifdanmelakukan antisipasi terhadap dampakyang mungkin akan terjadi.

Analisis data atas persepsi masyarakat terhadap ekosistem DAS menggunakan data scoring yang dianalisis secara deskriptif kualitatif. Penentuan skor diawali dengan memberikan skor pada masing-masing komponen dengan skor maksimal 5,0 dan skor minimal 1,0. Dari hasil analisis menunjukkan bahwa rata-rata persepsi masyarakat hulu terhadap peranan ekosistem DAS dalam pelestarian air adalah sebesar 3,77 tergolong dalam kategori tinggi. Katagori baik dalam hasil penelitian ini menunjukkan bahwa masyarakat hulu memahami bahwa kondisi ekosistem DAS akan menentukan keberlanjutan sumberdaya air di Sungai Ayung. Masyarakat hulu menyadari bahwa keberadaan ekosistem akan menentukan jumlah mata air dan debit mata air yang muncul di kebunkebun petani setempat dan juga pada lerenglereng tebing sungai. Keberadaan ekosistem DAS tidak hanya menentukan keberlanjutan ketersediaan air tetapi juga berperan dalam konservasi tanah, khususnya dari ancaman erosi dan sedimentasi.

Berdasarkan penuturan responden beberapa tahun silam sebelum banyak terjadi alih fungsi lahan dan alih fungsi vegetasi di wilayah DAS ditemukan banyak sumber air yang mengalir melalui mata air yang bermunculan di musim hujan di kebun-kebun dan tebing atau jurangjurang sekitar sungai. Pada musim kemarau airnya 
tetap mengalir sekalipun dalam debit yang relatif sedikit menurun. Air yang keluar dari beberapa mata air ini berwarna jernih kemudian dimanfaatkan secara langsung oleh masyarakat sekitar disamping juga mengalir pada beberapa sungai kecil yang ada di bawahnya yang pada akhirnya bermuara pada sungai besar yang disebut Sungai Ayung. Dengan demikian dapat dikatakan bahwa debit aliran Sungai Ayung sangat ditentukan oleh jumlah mata air yang terbentuk di hulu serta kondisi tanah dan vegetasi di wilayah DAS. Pada lahan dengan tutupan vegetasi yang rapat dan sistem perakaran kuat akan menjadikan fungsi hidrologis atau tata air dari ekosistem tersebut semakin baik, dan hal sebaliknya terjadi apabila tutupan vegetasi berkurang serta banyak tanaman semusim yang diusahakan akan menjadikan fungsi hidrologis DAS menurun.

Keberadaan ekosistem DAS yang baik tidak hanya memberi manfaat dari sisi pelestarian sumberdaya air semata tetapi juga memberikan manfaat kehidupan sosial ekonomi pada masyarakat sekitarnya. Masyarakat tidak hanya memanfaatkan lahan yang dimilikinya sebagai tanaman tahunan semata, namun mereka juga dapat memanfaatkan untuk budidaya tanaman semusim (palawija) dengan sistem tumpang sari. Pada saat tuntutan dan kebutuhan ekonomi relatif masih terbatas pendapatan dari kebun masih bisa mencukupi kebutuhan rumah tangga (cost of living). Namun perkembangan berikutnya menunjukkan bahwa tuntutan hidup dan ekonomi manusia semakin meningkat dan ini menjadikan masyarakat melakukan berbagai upaya dalam pemenuhan kebutuhan tersebut, termasuk diantaranya adalah merubah vegetasi yang tumbuh di atas lahannya menjadi tanaman yang lebih produktif dan bernilai ekonomi.

Dari aspek peranan ekosistem DAS, masyarakat sangat memahami pentingnya pelestarian ekosistem karena ekosistem hutan, DAS dan pohon-pohon yang tumbuh di atasnya sangat penting dalam menjaga air di daerah hulu. Merusak hutan dan DAS berarti merusak ketersediaan air dan bahkan mereka mengatakan tidak ada hutan berarti tidak ada air. Mereka juga tidak mau dipersalahkan sepenuhnya atas terjadinya kerusakan hutan dan DAS di daerah hulu karena perambahan hutan dan perubahan fungsi justru banyak dilakukan oleh orang lain dari luar daerah setempat.

Ada sisi menarik dari penelitian ini adalah bahwa mereka tidak setuju apabila tanggung jawab dan beban dalam pemeliharaan dan pelestarian DAS hanya dibebankan pada masyarakat hulu. Peranan dan tanggungjawab pemerintah dan pengusaha wajib terlibat dalam pelestarian DAS. Pemerintah sebagai pemegang regulasi diminta tidak hanya sebatas membuat peraturan dan kebijakan semata dalam pelestarian sumberdaya hutan dan DAS tetapi juga ikut berperan dalam pemberdayaan ekonomi masyarakat setempat sehingga taraf hidup dan perekonomian masyarakat meningkat sehingga tidak lagi melakukan kegiatan yang dapat merusak hutan dan DAS. Demikian juga pihak swasta seperti PDAM dan Perusahan AMDK dan Rafting yang memanfaatkan jasa ekosistem DAS (air) haruslah juga bertanggungjawab dan berkontribusi dalam pelestarian DAS. Ketiga perusahan tersebut seharusnya mengalokasikan sebagaian dananya baik dalam bentuk CSR atau bentuk dana lain dalam pelestarian DAS. Dana tersebut dialokasikan untuk pelestarian dan konservasi DAS yang direncanakan dan dilakukan secara terpadu dan terintegrasi antar para stakeholder.

\subsection{Hubungan Persepsi dengan Perilaku Masyarakat Hulu Terhadap DAS}

Persepsi masyarakat yang tinggiatas keberadan ekosistem DAS dalam pelestarian sumberdaya air ternyata diikuti oleh perilaku dengan kategori sedang dalam tindakan konservasi. Berdasarkan persespsi, bahwa mereka tidak setuju apabila pohon-pohon yang besar yang tumbuh di dekat lahan miring ditebang dan mereka juga setuju menanam pohon dengan sistem perakaran yang kuat pada lahan miring sehingga erosi bisa dicegah. Namun dalam tindakan atau perilaku, mereka justru membudidayakan tanaman 
semusim pada lahan yang miring. Hal ini tentu tidak sejalan dengan kaidah-kaidah konservasi karena budidaya tanaman semusim (seperti palawija) tidak mampu mencegah terjadinya erosi tanah di musim hujan. Tindakan ini dilakukan masyarakat setempat karena secara ekonomi mereka tidak bisa mengaharapkan sepenuhnya hasil tanaman tahunan, seperti kopi, kayu dan tanaman sejenis lainnya untuk mencukupi kebutuhan ekonomi sehari-hari. Mereka menanami kebun dengan tanaman yang bersifat quick yielding dengan hasil panen yang bisa dilakukan dalam waktu yang cepat dan terus menerus.

Umumnya persepsi yang dimiliki seseorang akan sesuai dengan perilaku yang dimunculkannya. Artinya, apabila seseorang mempunyai persepsi tentang sesuatu yang dinyatakannya tinggi atau positip maka perilaku yang dimunculkannya juga perilaku positip terhadap sesuatu tersebut. Tetapi adakalanya muncul ketidak sesuaian antara persepsi dan perilaku. Seperti yang dikemukakan oleh Brehm dan Kassin(1990),yang menguraikan bahwa ketidak sesuaian antara persepsi dengan sikap dan perilaku seseorang diakibatkan oleh kurangnya peran kesadaran dan rasa tanggungjawab personal dalam dirinya. Kebebasan memilih berkaitan dengan keterpaksaan melakukan suatu perilaku.
Apabila seseorang dipaksa oleh situasi atau kondisi untuk melakukan tindakan atau perilaku yang tidak sesuai dengan persepsinya maka ia tidak akan merasakan adanya tanggungjawab atas masalah tersebut.

Persepsi menjadi hal yang penting dalam menentukan sikap dan perilaku yang akan dilakukan masyarakat. Masyarakat yang tahu dan sadar akan dampak yang ditimbulkan dari perubahan ekosistem DAS terhadap keberlanjutan sumberdaya air akan diimplementasikannya dalam bentuk upaya dan usaha konservasi. Namun manakala tindakan atau perilaku konservasi yang dilakukan itu dirasakan tidak memberikan manfaat yang berarti bagi dirinya sendiri atau komunitasnya maka tindakan tersebut tidak akan dilakukannya dengan sepenuh hati. Apabilaseseorangmelakukan tindakan atau perilaku yang tidak sesuaidengan persepsinya itu berarti bahwa iatidak merasakan adanya tanggungjawab atas masalah tersebut

Dari hasil analisis korelasi Spearman Rank mempergunakan Program Paket SPSS Versi 20 mendapatkan hasil seperti terlihat pada Tabel 3 berikut.

Tabel 3. Nilai Korelasi Antara Persepsi dan Perilaku

\begin{tabular}{|c|c|c|c|c|}
\hline & & & Perilaku & Persepsi \\
\hline \multirow{6}{*}{ Spearman's rho } & \multirow{3}{*}{ Perilaku } & Correlation Coefficient & 1,000 & 0,003 \\
\hline & & Sig. (2-tailed) & . & 0,984 \\
\hline & & $\mathrm{N}$ & 50 & 50 \\
\hline & \multirow{3}{*}{ Persepsi } & Correlation Coefficient & 0,003 & 1,000 \\
\hline & & Sig. (2-tailed) & 0,984 & . \\
\hline & & $\mathrm{N}$ & 50 & 50 \\
\hline
\end{tabular}

Berdasarkan perhitungan seperti terlihat pada Tabel 3 di atas diperoleh nilai rho $_{x y}=0,003$. Dengan menggunakan taraf signifikansi $5 \%$ menunjukkan bahwa tidak terdapat hubungan antara persepsi dengan perilaku masyarakat dalam upaya pelestarian ekosistem DAS menuju sumberdaya air berkelanjutan di Sungai Ayung.

Tidak adanya hubungan antara persepsi dan perilaku dalam penelitian ini menunjukkan bahwa masyarakat hulu merasakan bahwa tanggungjawab pelestarian ekosistem DAS dalam bentuk 
konservasi tidaklah sepenuhnya menjadi tanggung jawab masyarakat hulu semata tetapi menjadi tanggung jawab semua stakeholder yang memanfaatkan jasa ekosistem DAS itu sendiri. Dilanggarnya kaidah-kaidah konservasi dalam teknik budidaya tanaman dan juga jenis vegetasi yang diusahakan lebih berdasar pada alasan ekonomi semata. Sekalipun masyarakat sadar bahwa tanaman semusim tidak baik diusahakan pada lahan miring dan juga digantinya tanaman kopi menjadi tanaman jeruk adalah karena alasan ekonomi yang mengalahkan alasan pelestarian lingkungan. Dengan berbudidaya tanaman semusim seperti palawija dan hortikultura mereka dapat penghasilan setiap hari dari hasil panennya, dan hal yang tidak mungkin didapat apabila mereka hanya menanam tanaman kayu yang baru bisa dipanen dalam jangka waktu yang panjang, lebih dari lima tahun. Demikian juga menanam tanaman jeruk jauh lebih menguntungkan dibandingkan dengan tanaman kopi. Jeruk dapat dipanen beberapa kali dengan harga jual yang relatif tinggi, sedangkan kopi rata-rata hanya bisa di panen 1-2 kali setahun dengan harga yang tidak pasti dan cendrung rendah.

Dalam berbudaya tanaman ini mereka juga sadar apa yang dilakukannya tidak sesuai dengan asas pelestarian sumberdaya air. Namun bagi mereka itu tidak menjadi masalah yang serius karena air yang merupakan jasa lingkungan ekosistem DAS justru akan lebih banyak dinikmati oleh masyarakat tengah dan hilir bukan di masyarakat hulu. Mereka memanfaatkan air sungai atau mata air dengan menggunakan pompa hydram atau teknik lain melalui swadaya kelompok. Mereka merasakan tidak ada keberpihakan pemerintah atau stakeholder di daerah hilir dalam membantu mereka menyediakan air bersih, namun disisi lain mereka dituntut untuk terus melakukan pelestarian sumberdaya air. Adanya ketidakadilan ini menjadikan mereka bertindak sesuai dengan kepentingan dan kebutuhan mereka sendiri sekalipun apa yang dilakukannya dirasakan tidak sesuai dengan kaidah-kaidah konservasi.
Berdasarkan hasil analisis tersebut menunjukkan bahwa kegiatan konservasi dan rehabilitasi ekosistem tidak hanya dapat dibebankan kepada masyarakat hulu saja tetapi juga memerlukan pelibatan banyak pihak (stakeholder), mulai dari stakeholder kunci (pemerintah, selaku pihak pengambil keputusan), stakeholder primer (pihak yang mempunyai kepentingan langsung dengan program), dan stakeholder skunder (pendukung). Positipnya persepsi akan arti DAS dalam menjaga keberlanjutan pasokan sumberdaya air Sungai Ayung seharusnya juga dibarengi dengan sikap para stakeholder pengguna air dan pemerintah untuk melakukan pengelolaan DAS secara terpadu dengan memperhatikan aspek social ekonomi masyarakat hulu. Masyarakat hulu jangan hanya dijadikan sebagai obyek dalam pelestarian DAS semata, tetapi juga memposisikan perannya sebagi subyek untuk ikut terlibat dalam menyelesaikan masalah DAS dengan mendengar aspirasi keinginannya.

\section{Simpulan dan Saran}

\subsection{Simpulan}

Berdasar pada uraian tersebut di atas maka beberapa butir simpulan yang dihasilkan dalam penelitian ini adalah sebagai berikut.

1. Jasa hidrologis hutan berupa sumberdaya air merupakan salah satu jasa lingkungan terpenting yang dihasilkan oleh ekosistem DAS yang berada di hulu Sungai Ayung. Hasil penelitian menunjukan bahwa telah terjadi penurunan fungsi hidrologis fungsi DAS Ayung akibat berbagai kegiatan manusia seperti perubahan penggunaan lahan yang tidak mengikuti kaidah-kaidah konservasi dan perubahan peruntukan.

2. Persepsi masyarakat hulu terhadap peran ekosistem DAS dalam pelestarian sumberdaya air berkelanjutan di Sungai Ayung termasuk dalam kategori baik/tinggi.

3. Tindakan dan perilaku masyarakat hulu dalam melakukan konservasi wilayah DAS di 
daerah hulu termasuk dalam kategori sedang, dan itu berarti bahwa tidak ada hubungan antara persepsi dengan perilaku dalam pelestarian ekosistem DAS Ayung.

\subsection{Saran}

1. Tanggungjawab konservasi DAS tidak bisa dibebankan sepenuhnya hanya kepada masyarakat hulu, namun harus melibatkan berbagai stake holder penyedia dan pengguna air yang dihasilkan oleh jasa ekosistem DAS.

2. Dalam pengelolaan DAS menuju ketersediaan sumberdaya air berkelanjutan di Sungai Ayung maka para pihak atau stakeholder yang terlibat didalamnya harus melakukan kegiatan yang terpadu dan terintegrasi baik antar sektor maupun antar wilayah sehingga terjadi sinergitas dan sinkronisasi dalam pencapaian tujuan.

3. Dalam upaya pelestarian ekosistem sumberdaya DAS ke masa depan prinsip "penerima manfaat membayar" dalam DAS perlu dipikirkan sehingga para pihak merasa memiliki dan bertanggung jawab terhadap keberadaan DAS dan terjadinya efisiensi dalam penggunaan air sungai.

\section{Daftar Pustaka}

1999. Undang Undang Republik Indoensia No. 32 Tahun 2009, Tentang Perlindungan dan Pengelolaan Lingkungan Hidup. Jakarta.

2004. Rencana Pengelolaan Secara Terpadu Daerah Aliran Sungai Ayung. Hasil Penelitian Kerjasama Bappeda Provinsi Bali Dengan Pusat Penelitian Lingkungan Hidup Universitas Udayana, Denpasar.

Adnyana, Sandi. 2007. Pengelolaan Terpadu Daerah Aliran Sungai Ayung. Jurusan Tanah, Fakultas Pertanian, Universitas Udayana. Denpasar

Al-Rasyd H., dan T. Samingan. 1980. Pendekatan Pemecahan Masalah Kerusakan Sumberdaya Tanah dan Air Daerah Aliran Sungai Dipandang dari Segi
Ekologi. Laporan No. 300. Lembaga Penelitian Hutan. Bogor

Asdak, Chay, 2007. Hidrologi dan Pengelolaan Daerah Aliran Sungai. Penerbit Gadjah Mada University Press, Yogyakarta.

Cicin-Sain and Knecht. 1998. "Integrated Coastal and Marine Management". Washington Press. Washington DC.

Cole, Rebecca J., 2010. Social and Environmental Impacts of Payments for Environmental Services for Agroforestry on Small-Scale Farms in Southern Costa Rica. International Journal of Sustainable Development and World Ecology. London: Jun 2010. Vol. 17, Iss. 3; pg. 208

Hulfschmidt, M. 1985. A Conceptual Framework for Analysis of Watershed Management Activities. Environment and Policy Institute. East West Center. Honolulu.

ICRAF, Ford Foundation, LP3ES, Bappenas, WWF-Indonesia. 2005. Strategi Pengembagan Pembayaran dan Imbal Jasa Lingkungan di Indonesia. Laporan Lokakarya Nasional, Jakarta, 14-15 Februari 2005

Irwan, Zoer'aini Djamal, 2007. Prinsip-Prinsip Ekologi. Ekosistem, Lingkungan dan Pelestariannya. Penerbit Bumi Aksara, Jakarta.

Jiang, Yi, Leshan Jin, Tun Lin, 2010.Higher Water Tariffs for Less River Pollution Evidence from Min River and Fuzhou City, People's Republic of China. Asian Development Bank Economics Working Paper Series No. 201.

Manan, S. 1979. Pengaruh Hutan dan Managemen Daerah Aliran Sungai. Fakultas Kehutanan, Institut Pertanian Bogor.

McAfee, Kathleen, Elizabeth N Shapiro. Payments for Ecosystem Services in Mexico: Nature, Neoliberalism, Social Movements, and the State. Association of American Geographers. Annals of the Association of American Geographers. Washington: Jul 2010. Vol. 100, Iss. 3; pg. 579. 
Odum, E.P. 1971. Fundamentals of Ecology. W.B. Saunders Company, London.

Ostrom, E. 1990. Governing the Commons : The Evolution of Institution for Collective Actio. Cambridge : Cambridge University Press.

Pagiola, S., A. Arcenas, and G. Platais (2005), 'Can Payments for Environmental Services Help Reduce Poverty? An exploration of the issues and the evidence to date from Latin America', World Development 33: 237-253.

Pereira, S.N.C., 2010. Payment for Environmental Services in the Amazon Forest: How Can Conservation and Development $\mathrm{Be}$ Reconciled? Journal of Environment \& Development. La Jolla: Jun 2010. Vol. 19, Iss. 2; pg. 171.

Ratnaningsih, Maria, 2008. Pengelolaan Daerah Aliran Sungai Cimanuk Terpadu Dengan Pendekatan Pembayaran Jasa Lingkungan. Disertasi, Program Studi Ilmu Lingkungan, Program Pascasarjana Universitas Indonesia. Jakarta.

Sheng. T. C. 1968. Concepts of Watershed Management. Lecture Notes for Forest Training Course in Watershed Management and Soil Conservation. UNDP/FAO. Jamaica.
Silalahi, Uber. 2009. Metode Penelitian Sosial. Penerbit PT Refika Aditama, Bandung.

Singarimbun, Masri, Sofian Effendi, 1989. Metode Penelitian Survai. LP3ES, Jakarta.

Southgate, D., Timothy Haab, John Lundine, Fabian Rodriguez, 2010. Payments for Environmental Services and Rural Livelihood Strategies in Ecuador and Guatemala. Environment and Development Economics. Cambridge: Feb 2010. Vol. 15, Iss. 1; pg. 21, 17 pgs.

Sudarma, I Made, 2013. Pembayaran Jasa Lingkungan Sebagai Instrumen Ekonomi Menuju Pengelolaan Daerah Aliran Sungai Ayung Berkelanjutan di Provinsi Bali. Disertasi, Program Studi Ilmu Ekonomi, Program Pascasarjana Universitas Udayana. Denpasar.

Sugiyono, 2010. Metode Penelitian Kuantitatif Kualitatif dan $R \& D$. Penerbit Alfabeta, Bandung.

Wunder, S., 2008. Payments for Environmental Services and Tthe Poor: Concepts and Preliminary Evidence. Environment and Development Economics 13: 279-297. 